\title{
Fixed Specimen
}

National Cancer Institute

\section{Source}

National Cancer Institute. Fixed Specimen. NCI Thesaurus. Code C84514.

Tissue which is preserved in a fixative solution, usually formalin. 